\title{
LESS RISKY INVESTMENT? THE IMPACT OF FEDERALISM ON THE INFLOW OF FOREIGN DIRECT INVESTMENT
}

\author{
A Thesis \\ presented to \\ the Faculty of the Graduate School \\ at the University of Missouri-Columbia \\ In Partial Fulfillment of the \\ Requirements for the Degree of \\ Master of Arts \\ in Political Science
}

by
ELDAR F.RIZVANOV

Dr. A. Cooper Drury, Thesis Supervisor

MAY 2014 
The undersigned, appointed by the dean of the Graduate School, have examined the thesis, entitled

\section{LESS RISKY INVESTMENT? THE IMPACT OF FEDERALISM ON THE INFLOW OF FOREIGN DIRECT INVESTMENT}

presented by Eldar Rizvanov, a candidate for the degree of Master of Arts

and hereby certify that, in their opinion, it is worthy of acceptance.

Professor A. Cooper Drury

Professor Simone Dietrich

Professor Christopher Otrok 


\section{ACKNOWLEDGEMENTS}

I would like to express sincere gratitude to my thesis advisors, A. Cooper Drury,

Simone Dietrich, and Christopher Otrok, for their help and suggestions in completing this paper. This thesis would not have been possible without their insightful input and comments. All mistakes are mine alone. 


\section{LIST OF TABLES}

Table 1: List of Summary Statistics $\quad 22$

Table 2: The Impact of Administrative Federalism 34

Table 3: The Impact of Fiscal Federalism 35

Table 4: The Impact of Political Federalism 38 


\section{LIST OF FIGURES}

Figure 1: FDI into China $\quad 23$

Figure 2: FDI into India $\quad 23$

Figure 3: Tsline $\quad 25$

Figure 4: Distribution of the Dependent Variable 26

Figure 5: Marginal Effect of Fiscal Federalism 37 


\section{TABLE OF CONTENTS}

I. Acknowledgements ii

II. INTRODUCTION: Globalization, Federalism, and Foreign Direct Investment 1

III. MAIN BODY

a. Literature Review

i. Foreign Direct Investment and Multinational Corporations 3

1. Race for the FDI 4

2. Unequal Spread of the FDI 5

3. Strategic Behavior of Multinational Corporations 6

ii. Federalism and Quality of Governance 8

1. Mechanisms of Federalism 9

2. Economic Theory 10

b. Theory Section

3. Defining and Operationalizing Federalism 11

i. Varieties of Federalism $\quad 12$

ii. The Argument 16

iii. Volatility of Policy and Economic Growth 19

$\begin{array}{ll}\text { iv. Counterargument? } & 21\end{array}$

c. Empirical Section

i. Preliminary Evidence 22

ii. Models 25

iii. Variables: Definition and Sources 26

1. Additional Model Specifications 33

iv. Results 33

v. Race to the Bottom and Fiscal Federalism 39

IV. Conclusion 41

V. Bibliography 43

a. Appendix I: Summary Statistics 51

b. Appendix II: Tsline 52

c. Appendix III: Regression Tables without Central Bank Independence 53 


\section{Globalization, Federalism, and Foreign Direct Investment}

Federalism is a relatively familiar and well-researched concept that has recently enjoyed a new wave of interest from political scientists. The reason for such a revival lies primarily in the fact that this is a strategy that is being utilized by an increasing number of developing nations in their quest for rapid economic self-development and growth (e.g., see Bird 1993; Rodden 2004). In particular, many less developed countries (LDCs) implement federalism and decentralization in order to gain credibility in the political arena and achieve greater efficiency in terms of economic performance. Diffusion of power and authority from the national to state and local governments is widely associated with an ability to radically improve the quality of governance (Fan et al. 2008; Rondinelli 1989, 59-60; White 2011).

As a policy direction, the move towards decentralization among developing countries began to take strong roots during the 1980s, encouraged by successful experiences of the developed world (Oxelhein 1993, 11). With the potential to satisfy both the right's call for greater efficiency and the left's appeal for a more even distribution of power, pressures for decentralization arose both internally and externally. Multinational corporations, freer trade, and internationalization of business all had forced central governments to reconsider the role they play in the economy and society. As a result, "subnational governments are now doing a larger share of the work of government in both developed and the developing countries" (Schneider 34). As this policy choice was becoming increasingly popular, it captured the attention of political scientists. A plethora of new research agendas and programs arose that explored the impact of federalism and decentralization on a variety of socially relevant phenomena, such as the 
quality of governance (Weingast 1995), corruption (Treisman 2000), economic growth and development, and the size of the government (Jin and Zou 2002; Stein 1999), quickly came to dominate this research area.

One particular incentive for decentralization is the desire to attract foreign direct investment (FDI) by multinational corporations (MNCs). By the means of increasing the number of "veto points" within governments, federalism is purported with reducing uncertainty involved in future government policy, thereby lowering the risk of governments' reneging on the original terms of contracts with the multinationals, which reduces their risks of losing overseas profits and production. The hypothesized relationship in this research project, therefore, is that the presence of federalism should make a nation a more favorable target of foreign investment in the eyes of a multinational. Subsequently, one is led to expect that nations with higher degrees of federalism should, ceteris paribus, experience higher volumes of FDI. The goal of this paper is, therefore, twofold. First, I will test separately these types of federalism in order to determine whether any of them exert a significant effect on the flow of FDI into a country. Second, based on the findings, I will attempt to propose new areas of research that explore these individually, as well as in interaction with one another.

The remainder of the paper proceeds as follows. First, I will briefly discuss the growing importance of foreign direct investment from the perspectives of both multinational corporations and host governments. Second, I will overview the normative and positive theories of federalism, point out common flaws of previous research, and finally, postulate about the possible connection between federalism and foreign direct 
investment. Thirdly, I will outline the policy stability argument, and fourthly, I will empirically test the hypotheses outlined using available data. The final section concludes.

\section{Foreign Direct Investment and Multinational Corporations}

With ever increasing levels of globalization in recent decades (das Neves 2012, 15), nations have become more and more integrated if one considers the amount of cash and other forms of capital that are being transferred across national borders (Casi and Resmini 2012,95). While the benefits of globalization abound, one negative consequence is that it adds another dimension to states' competition for power and money- their ability to attract foreign direct investment (Chan and Clark 1995, 166). The substantial literature on globalization almost uniformly agrees that virtually every state today is engaged in policy manipulation designed to make their country more attractive in the eyes of multinationals. Before proceeding to causes and implications of foreign direct investment, it is necessary what exactly we mean by that term.

As laid out by Scott X. Liu (1997), FDI occurs "when a firm acquires[s] ownership control of a business unit in a foreign country." According to the United Nations Conference on Trade and Development (UNCTAD), an FDI is an "investment made to acquire lasting interest in enterprises operating outside of the economy of the investor." OECD Benchmark Definition of Foreign Direct Investment $(2008,49)$ defines a foreign direct investor as "an entity (an institutional unit) resident in one economy that has acquired, either directly or indirectly, at least $10 \%$ of the voting power of a corporation (enterprise), or equivalent for an unincorporated enterprise, resident in another country." 
Such ownership takes shape in one or more of the three basic forms:

1. Establishing a new subsidiary or branch ("greenfield investment");

2. Acquiring control share of an existing firm usually through a merger and acquisition; or finally,

3. Participating in a joint venture (Liu 1997)

Most importantly, however, foreign direct investment involves a transfer of capital from one country to another.

\section{Race for the FDI}

Occurring simultaneously with countries' move towards greater decentralization, the "global race" for FDI took off during the eighties, reaching astonishing $\% 185$ billion in 1989 (Oxelheim 1993, 11). According to a recent OECD report (2002, 6-7), the amount of FDI flow in the world had increased fourfold from 1995, reaching the figure of \$1.3 trillion (US) in 2000. So, what is the fuzz all about?

The main set of reasons why nations desire to attract foreign investment stems from the positive externalities that are believed to be brought about by the inflow of outof-country capital and resources, such as innovative technologies and previously unattainable skills (Blomstrom and Kokko 2003; Capello and Dentinho 2012, 96; Dutt 1998, 45; Javorcik 2004; Jensen et al. 2012, 4; OECD 2002, 5; Villaverde and Maza 2012; Wang 2010; Zhang et al. 2010). For example, Javorcik (2004, 625) finds in the case of Lithuania that foreign direct investment was significantly associated with the "spillover" effect on domestic firms and industries. He concludes his research by stating that leakage of foreign know-how occurs through both backward (agreements between 
domestic suppliers and foreign firms) and forward ("interactions between foreign suppliers of intermediate inputs and their domestic customers") linkages. In a similar study, Wang (2010) finds that spillovers occur via inter-industry linkages in his case study of Canada.

Zhang et al. (2010) find that the specific mechanisms through which FDI increases productivity of domestic firms include not only the introduction of new technology, but also more efficient and effective managerial practices. His sample of Chinese manufacturing firms examined over the period of 1998-2003 also reveals that the absorption of foreign know-how also depends on the domestic firms' capacity to learn; furthermore, maximum learning occurs in those cases in which the technological gap between foreign and domestic firms is intermediate. Casi and Resmini (2003), however, argue that the benefits from FDI are far from "automatic" and that whether the host nation's productivity and output in fact does increase depends on its domestic firms' willingness to adopt the new practices.

\section{Unequal Spread of the FDI}

Before we can discuss which factors affect positive learning that comes with FDI, it is first necessary to note that not all countries are equally successful in the volume of foreign investment that they are able to draw to themselves. Indeed, as observed by several scholars, foreign direct investment tends to flow to the already well-developed countries, as well as several of the most promising developing countries. As a result of such dynamic, the spread of FDI is extremely uneven across the globe. 
Understandably, multinational corporations seem to avoid investing in those areas which are "being marginalized, precisely for [the] conditions that keep these areas underdeveloped because of the inability to attract both FDI and domestic capital" (de Soysa 2003, 118, brackets added). This occurs primarily due to structural governance characteristics of the potential host countries, such as the low levels of institutional development and a lack of well-developed human capital. The resulting "vicious cycle of low levels of investment and net outflows of capital from much of the poor world" keeps those countries permanently stuck in bad economic performance. The countries of subSaharan Africa represent perhaps the best example of such dynamics (Collier and Gunning 1999). Another curious tendency noted by scholars is the change in FDI patterns over time (Capello and Dentinho 2012, 4). Compared to previous several decades, in recent year the search for increased productivity and profits has led multinational to outsource on a task-by-task basis, rather than that of complete functions. These decisions are primarily based on the availability of information, merit of human capital, and some other factors.

\section{Strategic Behavior of Multinationals}

While there are plenty of criticisms of the homo economicus, which is the omniscient and perfectly calculating model of human behavior which the economics profession uses for building its theories, it is conventional to accept the proposition that corporations (in general) act in accordance with the principles of rational choice and instrumental rationality. Even though the limitations of data availability, cognitive processing, and moral hazard persist in the cases of business organizations, multinational corporations do nevertheless possess considerable capacity necessary for making 
informed business decisions. This suggests that multinationals can be safely expected to act rationally and strategically in their decisions "where and how much" to invest outside their own country.

It is also conventional to assume that profit-maximizing is the main objective driving corporate behavior. While there are firm-endogenous reasons why firms export their production (e.g., due to internal characteristics - see Bernard and Jensen 2004), potential host countries around the world are nevertheless in an active campaign to attract FDI. Comparative and international political economy scholarship has identified several important political factors that drive the decision of where to invest. Particularly, comparative scholars have identified the "quality of governance" to be one of the most important political factors determining the flow of FDI into a country.

Predictably, one of the most crucial factors has to do with the policies of (potential) host governments. Those countries which work actively to increase their attractiveness to multinationals tend to attract more foreign capital. This conjecture has been confirmed by empirical research. For example, Hardin and Javorcik (2011) found that investment promotion strategies represent fairly inexpensive but effective tools used by developing countries wishing to attract FDI. However, they also find that this strategy does not significantly help industrialized nations attract investment. Perhaps, the explanation lies in the fact that the business and economic environment in such countries is already favorable, so no effort is required on the part of the government.

One of the most comprehensive studies has been conducted by Steven Globerman and Daniel Shapiro (2002). Using a large-N study, they utilized six governance 
infrastructure variables for a sample of countries for the period between 1995-1997. The six governance indicators are intended to capture the various dimensions of an effective government, reflecting de Soysa's (2003, 119) and others' (e.g., Przeworski and Limongi 1993) "hunch" that it is "politics" rather than the regime type that is the determinant of socially desirable outcomes, such as economic growth or inflow of foreign direct investment. While relatively broadly, these six indicators are meant to capture state characteristics such as the stability of the political system, "rule of law, graft, regulatory burden, voice and political freedom, and government effectiveness" (Globerman and Shapiro 2002, 1902). They found those factors to be highly statistically significant in their models.

\section{Federalism and the Quality of Governance}

\section{Logic and Purpose behind Federalism}

One of the most persistent challenges in the business of constructing a government is striking the necessary balance between giving the government enough power in order for it to be able to preserve the market and ensure that "everybody plays fair" on the one hand, while keeping it from becoming excessively powerful as to turn it into a "predatory" "Leviathan" whose power causes it to act to the detriment of the very goals for which it was created (Oates 1985; also see Buchanan 1980 for the original argument). Several tools have been utilized in order to achieve such a balance, including the rule of law and checks and balances. Federalism is another way of achieving this goal. By "vertically" separating governmental power into several autonomous layers, the principle is to construct mechanisms of policymaking by diffusing it to as local level as 
possible thereby ensuring both effectiveness and maximum representation (de Soysa 2003, 120).

As has been mentioned in the introduction, due to its postulated effects of increasing accountability, effectiveness, and representativeness of government, federalism has been widely experimented with by second and third world countries starting in the decade of the 1980s as the optimal governance mechanism. One of the difficulties in studying federalism from scholarly perspective stems from the fact that it has been conflated and confused with other terms that are often associated with it, such as democracy and quality of governance. Indeed, earlier, pre-Riker (1964) scholarship (and in some cases even scholarship published after his seminal work) writings, exploring the dynamics of federal systems and their comparison with non-federal systems was frequently criticized for its inability to separate normative and positive considerations. In the next section, I will explore the arguments made in favor of federalism as related to ostensible improvements in the quality of governance. As discussion in the previous sections has hoped to convince the reader, multinational corporations pay a great deal of attention to the behavior of host country government as an indicator of their credibility and take those factors into account when making their business calculations.

\section{Mechanisms of Federalism: Veto Points Argument}

The foremost argument made in favor of federalism has to do with increased policy stability which it is purported to provide. The veto points argument, originally made by George Tsebelis (1995), helps explain why federal systems are characterized by

higher policy permanency. The gist of the argument is that the higher is the number of 
players in a political system that is required in order to change the status quo, the more stable are the policies produced by such governments. In his analysis, Tsebelis compared different institutions and partisan setups and found that Westminster-dominant and single-party systems, in which there is only one veto player, experience much higher policy volatility than presidential and coalitional governments. This occurs due to incongruity of opinions of political leaders. In single party systems, because its leaders exercise legislative power virtually unilaterally, there is greater policy volatility. In comparison, in presidential systems, such as that of the United States, in which the agreement of both the president and Congress is required, status quo is much more stable, especially in times of divided government. As will be shown in later sections, this is the baseline argument of this paper.

\section{Mechanisms of Federalism: Economic Theory}

The second main argument deals with the economic theory of federalism. As summarized by Qian and Weingast (1997), the first argument was originally made by Friedrich Hayek (1945) who asserted that better spending decisions can be made on as local a level as possible due to the fact that the government located closer to the people possesses better information concerning the needs to those people than a more central (and distant) government would. As succinctly summarized by White (2011), the logic is that "if a government can perform closer to the people it is meant to serve, the people will get more out of government and, in turn, will be more willing to accept that government's authority." 
The second argument, advanced by Tiebout (1956) in favor of federalism, is that the resultant competition between subnational units allows citizens to better satisfy their preferences in such a system by appealing to that level which is better able to "do its job." Yet another, somewhat less accentuated alleged benefit of federalism and decentralization lies in the greater stipulated innovation in such systems. According to this proposition, for the reason that local governments are in control of smaller pool of resources, they can be used as "laboratories" for policy experimentation since failures are more likely to be localized and hence smaller in terms of damage (Bretton 2000, 2).

Several studies have been conducted aimed at assessing the impact of federalism on several macroeconomic variables which should be relevant for multinational corporations when evaluating a country as a potential recipient of its capital investment. Albert Breton (2000) found in the cases of the US and Canada that judiciaries in both countries kept each layer of the vertical chain of the government from invading property rights of citizens.

\section{Defining and Operationalizing Federalism}

Perhaps, the most substantial flaw that has plagued federalism research has to do with difficulty and a lack of precision in conceptualizing and operationalizing federalism (Schneider 2003). In fact, the extreme difficulty in conceptualizing federalism has led political economist Michael Burgess (2006) to view federalism as a "microcosm of the problem with studying political science itself." As a result of such murkiness and imprecision, scholarship has failed so far to state decisively whether federalism indeed has the postulated effects on the quality of governance which its normative supporters 
claim for it, and has led scholars to contradictory results (Rodden 2004, 3; Blume and Voigt 2008). As Jonathan Rodden points out, lack of refined measures of federalism is the primary reason for insignificant and sometimes contradictory findings of federalism research found in the first generation of empirical research. Thee contribution of this project is that it seeks to use both relatively simple, dichotomous measures, as well as more informative continuous measures of federalism in order to assess the impact of decentralization on the flow of foreign direct investment into a country.

\section{Varieties of Federalism}

Based on a comprehensive review of the available literature, he proposes a tripartite definition of federalism by breaking it down into three types: fiscal, administrative, and political. The goal of this paper is to empirically assess the validity of the claim that federalism significantly impact the flow of FDI into a country by examining these different types of federalism. Next, I will discuss in more detail the distinction between the three types of federalism. I will then turn the reader's attention to the breakdown of the extent of federalism, using typology identified by Byrd (1993).

Fiscal federalism refers to the traditional economic conceptualization of federalism by capturing the notion of the relative levels of revenues and expenditure between the central and subnational government(s). While there are several way to empirically capture this notion, the most widely accepted method is by measuring the portion of subnational revenues/expenditures of the total revenues/expenditures, often expressed as a percentage. The larger is the portion of the overall taxation that is attributed to the subnational unit(s), the greater is the degree of federalism. 
Administrative federalism, according to the World Bank, "seeks to redistribute authority, responsibility, and financial resources for providing public service among different levels of government." It primarily deals with the provision of public goods, and is thus concerned with the civil service. In short, administrative decentralization defines the ways in which "political institutions turn policy decisions into allocative outcomes" (White 2011, 2). The World Bank, in agreement with others, divides administrative federalism into three degrees: deconcentration, delegation, and devolution. These represent different degree of decentralization, with deconcentration being the weakest, and devolution the most extensive, forms of decentralization.

While these are "distinct," it is important to keep in mind that they are merely ideal types, and are best thought of as arbitrarily chosen "points" along a continuous distribution. The distinctions are that in deconcentration the central government maintains tight control over the subnational units; power in this case is not "transferred" but is merely deconcentrated geographically. With delegation, the central government maintains considerable control over the subnational unit; however, that unit has some capability for independent decision making. With devolution, however, the central government almost entirely abdicates its powers to the subnational governments (Martinez-Velasquez and Timofeev 2010,3). The only control it has over the state level decision makers is significantly altering the structure of the relationship itself; hence, this type of arrangement is most reminiscent of a control type of relationship between the central and the state governments.

The third main type of decentralization is political federalism. The main goal of political decentralization is to improve citizens' ability to influence public decision 
making by giving them more say in the formation and implementation of public policies. Often accompanied by pluralistic politics, it is rooted in the idea that localization of decision making and elections of public officials is associated with more prudent and democratic decisions by improving politicians' knowledge of their constituency's needs and priorities and citizens' ability to convey such information to those officials and better monitoring and enforcement.

One thing that is clear is that these three concepts of decentralization are closely related and interrelated. For example, Rodden (2004) records simultaneous increase in all three types of federalism in his world sample for the period from 1970 to 1990 . For example, an increase in the share of revenue collected from central to subnational governments indicates a shift towards decentralization. However, such move tells nothing of the autonomy of subnational units. This concept is captured by the administrative and/or political federalism.

In spite of these differences, we observe a fairly high degree of correlation between the different kinds of federalism. One obvious reason for this correlation is the source of decentralization. Federalism despite its murkiness of definition and conceptualization, is widely associated with the normatively positive notions of improved and responsible, as well as responsive, governance, and giving more power to the people. It is no wonder then that one naturally expects nations which are decentralized in one dimension to be also decentralized, at least to some degree, in other dimension(s).

While these three types of federalism are closely related, Schneider (2003), by the means of confirmatory factor analysis of data from 1996 for sixty-eight countries, finds 
that they are also noticeably different. An interesting question that arises with this finding is "what implications do these different types of federalism have on the inflow of the FDI into a country, as well as whether an interaction of these factors exerts an independent effect on the flow of FDI into a country.

In the next section, I will discuss in greater detail the three types of federalism, the current and past research that has investigated the role of each on important macroeconomic and political phenomena, as well as my theory of the possible implications of each of these types of federalism on the inflow of foreign direct investment.

\section{Measurements of Federalism}

As hinted at before, it is a common pitfall in political science that while acts of government, as well as their subsequent effects and consequences on the society are relatively easy to measure and operationalize, operationalizing the structure of the government itself sometimes poses quite unexpected difficulties (Marks et al. 2008, 111). Federalism and decentralization are not exceptional in this regard.

While most of the literature surveyed agreed on the definition of types and dimensions of federalism, some challenge the apparently ubiquitous confusion of federalism and decentralization. For example, Blume and Lorez (2008) points out that the crucial distinction lies in the constitutional design. Federalist countries, such as the United States and Canada, constitutionally grant their respective states and provinces substantial autonomy over several major policy areas. On the other hand many countries 
which have been decentralizing cannot be considered federal because decentralization is not firmly ingrained in the political structure.

While Blume and Lorenz provide a valid criticism, it is important to keep in mind that if one is to follow their advice, the number of countries considered federal for any type of quantitative analysis would have been dramatically curtailed. Furthermore,

considering the research question and theory presented ahead, following the rule of constitutional design would be unjustified in terms of the sacrifice on variation in the data it would pose and, as the theory section will prove, such distinction bears little consequence on the theory at hand.

\section{Theory}

The argument made in this paper is largely based on and adds another extension to the Tsebelis' argument concerning veto points. In its simplest form, it states that the number of veto points should be directly related to the stability of polity. The higher is the number of veto points, the less volatile policy stability tends to be. The logic behind this argument is fairly straightforward. Policy is much more volatile (i.e., likely to shift) if an agreement of only one decision maker is required, whereas it is much more likely to remain consistent if simultaneous agreement of several decision makers is required in order to change the status quo. As Quan Li summarizes it, "the dispersion of power the constrained executive, the large number of veto players over public policy, and the independent judiciary, collectively serve to strengthen the rule of law" $(2006,64)$. Federalism, then, is just another mechanism that increases the number of veto points. 
Policy stability, in turn, is positively and directly related to greater investment by foreign corporations. Underlying this argument is the implicit assumption that corporations care about policy stability. And such assumption does not seem divorced from reality. Because corporations' major incentive is to increase profits, they are reasonably expected to, and conform very well to the behavior of strategically making both short and long-term choices in a future that is always uncertain. It becomes clear then that they should strongly prefer policy stability as it alleviates the risks of governments' reneging on their pledge or even downright expropriating a multinational's assets, thereby increasing expected benefits. Additionally, prescience of future economic conditions increases their ability to forecast future payoffs. Corporations, therefore, desire greater policy stability and greater number of veto points.

The positive (from the perspective of a multinational) benefit of federalism is that it provides greater policy stability because it increases the number of veto points. Fiscal federalism provides perhaps the best case in which we are likely to observe the postulated causal mechanism at work. The overall tax a corporation pays that is levied by several decision-makers is more likely to stay closer to the original (overall) level of taxation, because in unitary systems initiation and agreement of only one (the) decision-maker is required in order to shift policy. Compare that to fiscally federal systems in which in order for policy to shift, each decision maker will have to shift policy in the same direction by the same amount (e.g., equal percentage increase in corporate tax implemented by both state and federal governments).

Even more importantly, this scenario is very unlikely to occur if one considers the driving factors behind taxation policy, and the differences in those motivations across 
vertical layers of government. While federal government is concerned with the "big picture" of national foreign and domestic spending, state and local governments have completely different considerations in mind. Because they are driven by different factors, it seems extremely unlikely that shift in taxation policy between national, state, and local governments, will occur in the same direction simultaneously in the same direction. Hence, the "overall" (from the perspective of a multinational) taxation rate is much less likely to shift in fiscally federal systems than it is in unitary systems.

An important point that must be made in regards to this argument which makes it applicable towards a variety of situations is that it is largely irrelevant what kind of policy the host government pursues towards corporations wishing to invest in its economy. Whether the tax policy is favorable (tax exemptions compared to domestic firms) or unfavorable (higher rates of taxation for foreign firms), the fact that decision are made on two (or more) levels of government will, in federal systems, introduce lower levels of risks.

This mechanism can be easily extended to other forms of federalism. For example, the distinguishing feature of political federalism is that state and local officials are directly elected by the people instead of being appointed by bureaucrats and elected officials at a federal level. Because they do not "owe" their job to the national government, such state and local officials are more likely to exercise independent thinking and decision making than mere figureheads in politically unitary systems. Because provincial and local decision-makers exercise dominion over important policy areas which are consequential to multinationals (e.g., local environmental planning, 
zoning laws, other local regulations, etc.), political and administrative federalism are likely to be very important in corporations' decisions whether to invest in a country.

This theory can be expressed in one main research hypothesis, and three subhypotheses.

H1: Based on the veto points argument, federalism should be positively and directly associated with higher levels of foreign direct investment by multinational corporations.

Hla: Fiscal federalism is positively related to the inflow of foreign direct investment into a country: the more fiscally federal a nation is, the higher flows of FDI it should experience.

H1b: Political federalism is positively related to the inflow of foreign direct investment into a country: the more politically federal a nation is, the higher flows of FDI it should experience.

H1c: Administrative federalism is positively related to the inflow of foreign direct investment into a country: the more fiscally federal a nation is, the high flow of FDI it should experience.

H2: There is an interactive effect between different types of federalism. Ceteris paribus, nations which are both fiscally and politically federal, should experience higher inflows of foreign direct investment than unitary systems.

\section{Volatility of Policy and Economic Growth}

An analogous argument has been made in regards to economic development by Nooruddin $(2011,40)$, who argues that it is the volatility of change in the economic growth (i.e., how quickly and rapidly the rate of economic growth rates vary across time), rather than the "average" rate of growth per se, that matters most for economic development and modernization. Using case studies of several developing countries, he shows that those countries which experienced less rapid and dramatic "swings" in the rates of economic growth across time, tended to achieve higher levels of development. 
The role of the government in this argument is twofold: first, it is to convince domestic audiences to save money in order to spend more in the future; and second, to convince foreign investors that their country is safe for investment (Nooruddin 2011, 22). In order to accomplish both goals, government needs to be able to make credible commitments. In order for commitments to be viewed as credible, constraining mechanisms on actions of policy makers are necessary.

In order to motivate his argument, Noorddin uses the "veto players" argument that is the cornerstone of this paper's theory. The crux of his argument is fairly simple. Because economic development necessarily requires long-term planning and investment, political system needs to provide for a favorable economic and political environment which maintains long-term stability. Hence, policy which is believed by investors to remain stable across relatively long periods of time is more likely to incentivize them to pour their money into the economy. This is why the number of veto players is so crucial for economic development. Because larger number of veto players increases policy stability, it is postulated to increase economic output and development.

Essentially, the same argument is being made here. Because an increase in the number of veto players makes it more difficult for challengers to alter the status quo, greater policy stability is achieved, which increases the probability of the policy survivability and continuation into the future. Because the owners of capital can be more confident that the current policy is likely to prevail in the future, they are able to forecast and plan future payoffs from current investment, all of which causes them to invest in that particular country or environment. Hence, the higher is the number of veto players, the higher should be the level of investment into a country. 


\section{Counterargument?}

As is true with the vast majority of social science arguments and theories, one of the potential problems regarding this argument is that the opposite argument can be made. Particularly, one could argue that federalism could exert a significant negative effect on the inflow of FDI for the reasons of risk. The logic of such argument primarily deals with bureaucratic burden and lag, and has been articulately illustrated by Kessing et al $(2007,10)$ with a hypothetical example of a foreign investor wishing to finance a project in Germany:

"Investor who made the decision to build a plant in, say, Munich, has to deal with several governments: with the city government of Munich, with the district government in the district in which Munich is located, with the government of the state of Bavaria in which Munich is located, and with the federal government of Germany, as Munich also belongs to Germany."

As this example makes obvious, federalism can serve to greatly exacerbate the problems of risk because in such systems presence of multiple decision makers can indeed lead to more rather than less risk. Additionally, it may be argued that the bureaucratic holdup problem is also exacerbated in federal systems.

While the author of this project believes that the main argument of this paper is more valid than the counterargument, the potential benefit of carrying out an empirical study like this is that it will allow us to find the answer to this question with actual, real world data.

\section{Part III: Empirical Investigation}




\section{Preliminary Evidence}

In order to provide some preliminary evidence to support the argument outlined in the previous section, below I provide some summary statistics, as well as graphic plots of the inflows of FDI over the 40 year period into two countries which are roughly similar on many relevant political and economic characteristics, but which differ in terms of their position on federalism - India and China. While India is a highly developed federalist system, China is a very centralized one. Hence, an investigation of these two countries' inflows of FDI should provide some preliminary evidence establishing whether foreign investment and a nation's level of federalism are related in any meaningful way.

The table below provides a rough comparison of means and standard deviations of inflow of foreign investment between federal and centralized systems. These statistics were compiled based on the data used in the statistical analyses conducted in the empirical section below.

Table 1: Simple Summary Statistics

\begin{tabular}{ccccc}
\hline Type of system & $\begin{array}{c}\text { Average Inflow } \\
\text { of Foreign } \\
\text { Direct }\end{array}$ & $\begin{array}{c}\text { Standard } \\
\text { Deviation } \\
\text { Investment }\end{array}$ & Minimum & Maximum \\
\hline Federalist & $3.41 \mathrm{e}+09^{1}$ & $1.72 \mathrm{e}+10$ & $-2.83 \mathrm{e}+10$ & $3.40 \mathrm{e}+11$ \\
\hline Centralized & $1.96 \mathrm{e}+09$ & $4.87 \mathrm{e}+09$ & $-4.53 \mathrm{e}+08$ & $3.58 \mathrm{e}+10$ \\
\hline
\end{tabular}

As we can see from this table, federalist nations tend to, on average, experience much higher inflows of foreign direct investment than more centralized systems. The comparison of standard errors for the two groups of countries shows that the mean inflow

${ }^{1}$ A note on scientific notation: $3.41 \mathrm{e}+09$ is equivalent to $3.41 * 10^{9}$, i.e., $\$ 3,410,000,000$ 
of FDI into a federal country is likely to be statistically and substantively higher than the inflow of FDI into a centralized system. These simple statistics show as a fairly convincing preliminary evidence in support of the theory.

In order to make these observed patterns more concrete and specific, I will next turn to an examination of the graphs depicting the inflow of foreign direct investment into two countries that can serve as foremost examples of $\overline{\bar{a}}$ federalist and centralized systems respectively - India and China.

The reason why India and

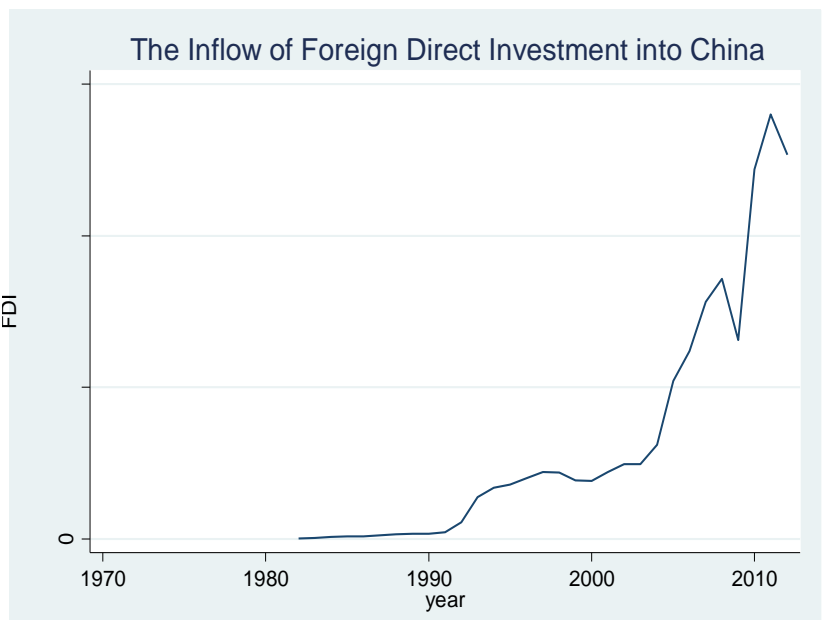
China provide good cases for such an

\section{Figure 1: FDI into China} investigation has to do with similarities between the two nations in terms of relevant politico-economic characteristics. Both countries represent lower-middle nations in terms

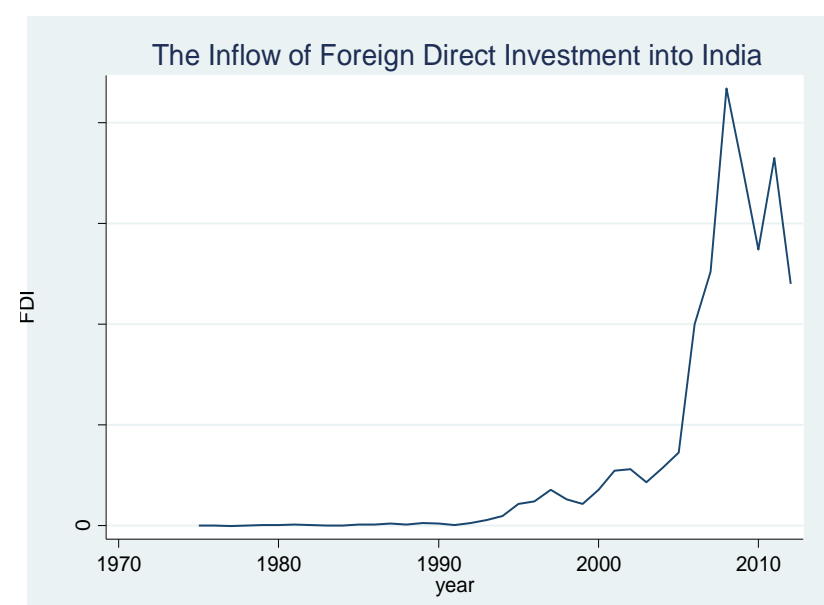

Figure 2: FDI into India of their levels of economic and political development, expressed in such criteria as the standard of living and wealth.

Furthermore, both nations feature important characteristics that exert both a positive and a negative effect on the inflow of foreign direct investment. While China has been actively conducting a campaign of market 
liberalization designed to modernize its system (Chen 1995), it remains a Communist nation, thereby causing natural suspicion among Western investors. India, on the other hand, while featuring a highly stable political system, its economic progress is hindered by persisting poverty and the presence of the so-called "marginal population." Also importantly, both nations share borders and are located in the same region, which allows us to rule out region-based explanations for the difference in the inflow of FDI between the two countries. Importantly, however, the two nations are different when it comes to their level of federalism. While India is a very well-developed federalist system, the Communist Party of China, unwilling to share its governmental power with provincial officials outside Beijing (and the party), have maintained a highly centralized form of governance in their country. As we can see from the axes labels, during the period examined, India has tended to attract higher inflows of foreign direct investment than has China.

While the presented evidence makes a fair case for the postulated positive influence of federalism on the inflow of foreign direct investment into a country, significance of this relationship cannot be reliably asserted with just preliminary data. In order to do that, I now turn to statistical tests of the empirical models postulated by the theory.

\section{Specifying the Model}

In order to empirically investigate whether the differences in the mean inflows of foreign direct investment between federal and centralized systems are, in fact, statistically

different, several statistical analyses were conducted using different measures and 
conceptualizations of federalism. In the most general form, the models run can be expressed as:

Logged FDI it $=\beta_{0}+\beta_{1}$ Federalism $+\beta_{2}$ Democracy $+\beta_{3}$ Logged Trade $+\beta_{4}$ OECD + $\beta_{5}$ Year $+\varepsilon_{i t}$

in which logged FDI is the natural log of the annual inflow of foreign investment in country $I$ in year $t$; Federalism is the variable for the particular dimension of federalism whose impact is being assessed; Democracy is the level of democracy; Logged Trade is the annual merchandized trade as a percentage of GDP; $O E C D$ is a dummy indicating whether a particular country was a member of the Organization for Economic Cooperation and Development; and Year is simply the year for each particular observation used in order to time-detrend the data. Below I discuss the data sources, as well as additional motivation for using this specific data in more detail.

\section{Variables Definition and Conceptualization}

\section{Dependent Variable}

The dependent variable is the inflow of foreign direct investment (FDI) into a

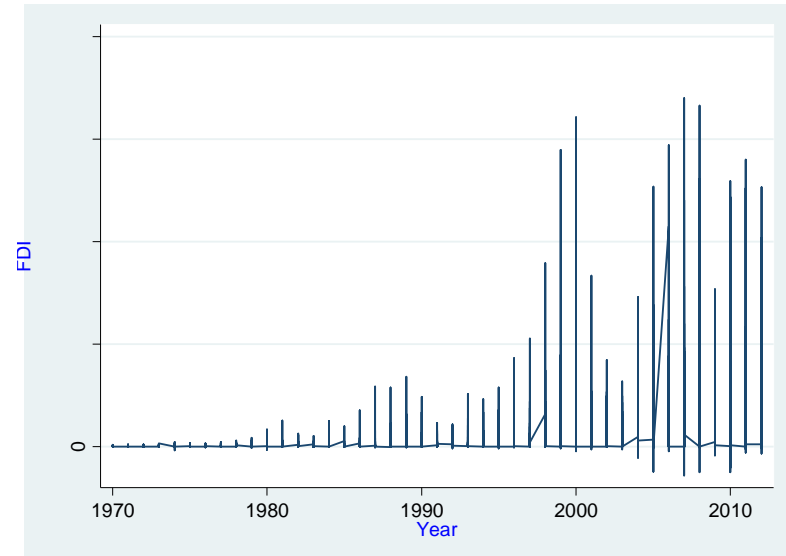

Figure 3: Tsline country. It is a continuous variable and is measured in current US dollars. The data is obtained from the World Bank World Development Indicators (WDI). This data is available for virtually every country in 
the world; primarily for the period between 1971 and 2012. Because this data directly measures the variable of interest, this is the only dependent variable that is used in this research. Because it is a continuous variable, ordinary least squares (OLS) regression is appropriate.

As the histogram bellows demonstrates, there are two potential problems with this variable. First, as the tsline plot depicting the bivariate relationship between FDI and time demonstrates, the data most likely suffer from non-stationarity.

In order to solve this problem, given the nature of non-stationarity, a time trend variable is appropriate. In this case, since the year variable is already present in the data, it will be used in the regressions to account for the time trend.
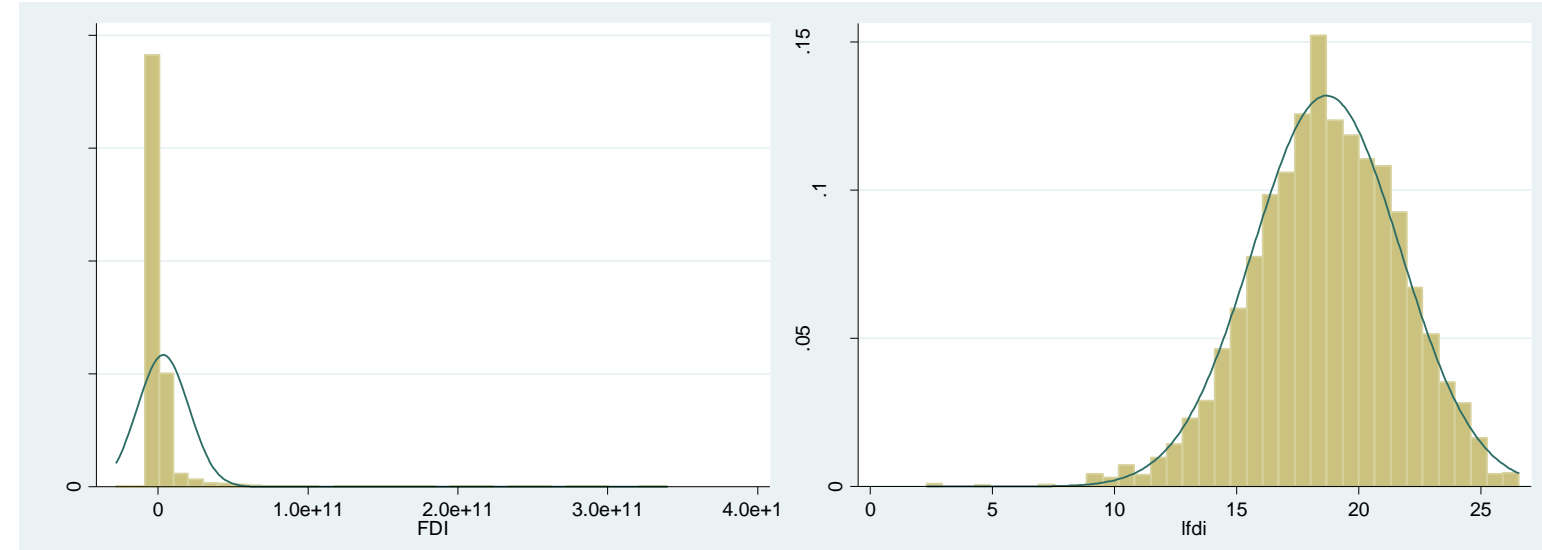

Figure 4: Distribution of the Dependent Variable: Level (Left) and Log (Right)

As the histogram of the dependent variable shows, however, another potential source of problem is the fact that the data is not normally distributed. While this problem does not seem particularly severe, a graph of logged FDI demonstrates a considerably better fit to the assumption of normality. Hence, a logged FDI variable is most appropriate for the analyses to be conducted. 


\section{Independent Variables}

\section{Administrative Federalism}

As Rodden (2004, 486) points out in his revisionist article "Comparative Federalism and Decentralization," the issue of administrative federalism has been largely overlooked by scholars due to the difficulty of its measurement. Thankfully, this empirical gap has been alleviate by Brown economist J. Vernon Henderson. In order to measure administrative federalism, Henderson asks whether countries possess certain key characteristics that are distinguishing administratively fiscal and unitary systems.

In order to assess the presence of administrative federalism, Henderson asks several key questions, such as whether the national government has an authority to override the decisions made by lower (i.e., provincial and local) level bureaucrats. As is obvious from the discussion above, subnational "autonomy" makes little sense if the federal bureaucrats and decision makers may simply override their decisions which they simply do not like. The second main question which Henderson asks is which level of government is responsible for what he determines to be three key policy areas: primary education, infrastructure, and local policing. Using different weight systems, Henderson

combines the constituent variables into 6- and 9-dimension measures of policy/administrative federalism. Because I expect a positive relationship between administrative federalism and foreign direct investment, I expect a positive beta coefficient on that variable.

\section{Fiscal Federalism}


Several data sources are available for the variables of interest. In order to ensure robustness of my findings (especially if they prove to be significant), I will utilize different measures of federalism. The two databases that have been used for this project are the Comparative Political Dataset III, provided by the University of Bern, and the Government Finance Statistics, provided by the International Monetary Fund. Below, I will briefly discuss each of these sources.

Comparative Political Dataset III provides data on fiscal decentralization, fiscdec, which measures "the tax revenue of state and local government as percentage of total taxation." This data is available for the 21-year period from 1990 to 2011 for approximately 35 OECD and non-OECD countries.

Several considerations were driving the data collection and sample selection. Perhaps, the most important is the sample size. Because this research is interested in a comprehensive examination of the impact of federalism on the flow of foreign direct investment, the goal was to collect as much data as possible for as wide a variety of countries as the data permitted. Because of these reasons, while full analyses were conducted with this data, I also utilized a more comprehensive analysis by including the original data on fiscal federalism and decentralization taken from the International Monetary Fund.

The main independent variables that are used in order to assess the impact of fiscal federalism on the inflow of foreign direct investment is the subnational taxation/revenue expressed as a percentage of the total taxation/revenue. Below is the formula used to obtain these data. 
Fiscal decentralization $=\frac{\text { Local revenue } / \text { expenditure }+ \text { State revenue } / \text { expenditure }}{\text { Total revenue } / \text { expenditure }}$

The higher the value, the higher is the degree of fiscal federalism. Because I expect the relationship between fiscal federalism and FDI to be positive, I expect the beta coefficient for fiscal federalism to be positive. The benefit of using a continuous instead of alternative ordinal variables (Blochiger \& Rabesona 2009) is that it allows one to more accurately capture the degrees of variation between different regimes which otherwise could have been classified in the same category if ordinal measures were used.

\section{Political Federalism}

Database of Political Institutions, published by the World Bank under the authorship of Phillip E. Keefer, and freely available for download, provides a dichotomous measure of political and administrative (as well as fiscal) federalism. While this measure is crude, it provides a fair operationalization of these two types of federalism. The variable author is a dummy for whether states and provinces have an authority over taxing, spending, and legislating. Words "taxes" and "spending" seem to refer more to fiscal decentralization, a state's ability to legislate points at least to some degree to political federalism.

Comparative Political Dataset I contains three measures of federalism. The first variable, fed, is trichotomous measure ("no," "weak," and "strong"), and is based on Huber et al. 2004. This variable is available for roughly the period from 1960 to 2011 for all of the countries, with the exceptions of Greece, Portugal, and Spain, for which the data is not available during earlier periods. Another variable for federalism, lfed, is only available for one (usually first) year for each country. Hence, it allows us to conduct a 
cross-national analysis only, without the temporal dimension. The third variable, lsec, is derived from Lijphart's second dimension of federalism.

Database of Political Institutions (2012) of the Development Research Group under the World Bank provides several variables which measure both fiscal and political federalism. The first variable, federal, is a dummy variable which records whether a nation is federal (1) or unitary (0).

The next two variables, state and muni, measure political federalism more directly. The second variable, state, is a trichotomous variable which indicates the presence and the scope of state elections. A value of " 0 " indicates no state elections; a value of " 1 " indicates that the executive(s) is appointed while legislature is elected; a value of " 3 " indicates that both the executive(s) and the legislature are elected at a state/provincial level.

The third variable, muni, is also a trichotomous variable which indicates presence and the scope of local elections. A value of " 0 " indicates that neither local executive(s), nor its legislature is elected locally. A value of " 1 " indicates that the local executive(s) is appointed while its legislature is elected; a value of " 3 " indicates that both the executive(s) and the legislature are elected at a state/provincial level. Because I am interested in using both of these variables, I will conduct regressions using both additive and multiplicative terms. 


\section{Control Variables}

I use a battery of standard control variables that are ubiquitous in the literature on foreign direct investment: level of democracy, rule of law, the level of trade, and OECD dummy (Jensen 2003; Jensen 2008; Li and Resnik 2003; Strasavage 2002).

One of the most important control variables is the level of democracy. Taken from Policy IV compiled by Marshall and Jaggers (2002). The variable Democracy is on an additive eleven-point scale which is based on the adherence to the principles of political inclusiveness, electoral competitiveness, and constraints on executive action. While the role of regime type has for some time been a hotly debated issue, the work of Nathan Jensen has convincingly empirically demonstrate time and again that when all things are taken into consideration, regime type IS an important determinant of the inflow of foreign direct investment into a country.

As has been repeatedly asserted in the literature review section, multinational corporations tend to care a lot about the quality of governance in a country. The reason for that is simple: a government which does not govern well and systematically violates fundamental principles of "fair rule" creates doubts and suspicions in the multinational decision-makers concerning safety of their investment in that country. In order to account for this factors, I utilizes Kauffman rule of law (2012) as one of the control variables. As defined by the World Justice Project $(2012,8)$, this index gives countries ratings based on their degree of adherence to four "universal" principles (of justice): accountability, securities of persons and property, just and efficient law making and law-enforcement. Another quality of governance control variable used in these analyses is central bank 
independence. Presence of an independent central bank adds another significant veto player to the "game," as one of central banks' primary feature is to control inflation and unemployment through its management of the monetary supply (i.e., the amount of money in the circulation in the economy) (Cukierman and Webb 1995).

Finally, some scholars have found that there are regional effects associated with the inflow of FDI. One of the primary reasons for such dynamics deals with the fact that countries located in the same region tend to display similar macroeconomic and political characteristics, such as comparable levels of development and size of the economy. Because inclusion of many regional dummies would unnecessarily eat up precious degrees of freedom without a corresponding increase the explanatory power of the model, I utilize a dummy variable for whether a country was a member of OECD for each particular year ${ }^{2}$. Membership in this organization serves to significantly boost up the rating of a country in terms of its business climate and the development of the economy, and is necessary to take into consideration. It is important to notice that it was coded on the basis of not only the country, but also the year. I coded a country as having a value of " 1 " on the OECD dummy only in the cases in which it was actually a member of that organization. For example, while Czech Republic is coded as "1," indicating that it is a member of the OECD for the year 1995, its value for the year 1994 is equal to " 0. "

\footnotetext{
${ }^{2}$ The dataset provided, however, does feature a batter of regional dummies with sub-Saharan Africa as the base region. As replacing OECD dummy with regional controls demonstrates, however, only the North America dummy is statistically significant. As we can further speculate, this is probably caused by the United States and Canada, both of which are highly developed economies and the governments of which are considered highly reliable for multinational investors.
} 


\section{Additional Model Specification Issues}

As performing standard checks to ensure data normality has revealed, the data suffers from serial correlation. Serial correlation is a problem in which the errors are correlated across time, which poses potential problems for the analysis. The concern that this poses is that Ordinary Least Squares estimation assumes that the each "event" (observation) is independent from one another, which is obviously not true in any timeseries analysis in which the same data generating units are observed across time. Because we run the risk of overlooking such dependence between observations, OLS is likely to overestimate the significance of the independent variables, overlooking temporal dependence in the data. This results in artificially small standard errors and hence artificially large significance (Keele and Kelly 2005).

In order to correct for the violation of the assumption of no serial correlation, I utilize a standard correction for serial correlation by including a lagged dependent variable. While some (e.g., Achen 2000) view lagged dependent variable as a serious methodological pitfall due to its proclivity to dominate the regression and wipe out significance on any other regressors on the right-hand side, it is the most viable alternative in this case.

\section{Results}

In reporting the results of the analyses that were run for this project I will report the most interesting (read "significant") results first, starting with administrative federalism (Table 1), next assessing the effect of fiscal federalism, and lastly, analyzing of the effects of political federalism. The table 1 below reports the results assessing the 
impact of administrative federalism on the inflow of foreign direct investment. Model 1 assesses statistical and practical significance of the 6-dimension federalism variable, while model 2 assesses significance of the 9-dimension federalism variable.

\section{Table 2. The Impact of Administrative Federalism on the Inflow of Foreign Direct} Investment

\begin{tabular}{lcc}
\hline & $(1)$ & $(2)$ \\
VARIABLES & Model I & Model II \\
\hline \multirow{2}{*}{ Lag FDI } & $7.17 * * *$ & $9.68^{* * *}$ \\
& $(1.92)$ & $(2.89)$ \\
Federalism, 6-dimension & $0.5495^{* *}$ & \\
Federalism, 9-dimension & $(0.2271)$ & \\
& & $0.7454 * *$ \\
Logged Trade & & $(0.2704)$ \\
& & 0.5417 \\
Central Bank Independence & 0.5512 & $(0.3706)$ \\
Democracy & $(0.3772)$ & -0.4652 \\
& -0.2998 & $(2.3188)$ \\
OECD & $(2.5287)$ & -0.0031 \\
& 0.0434 & $(0.0543)$ \\
Year & $(0.0512)$ & $1.2820 * *$ \\
& $0.8824 *$ & $(0.6009)$ \\
Constant & $(0.5286)$ & $0.0742 * *$ \\
Number of Observations & $0.0788^{* *}$ & $(0.0242)$ \\
\hline
\end{tabular}

Robust standard errors in parentheses $* * * \mathrm{p}<0.01, * * \mathrm{p}<0.05, * \mathrm{p}<0.1$

As we can see, both the 6-dimensional and 9-dimensional operationalizations of administrative federalism are statistically significant at the most commonly accepted standard of statistical significance of 0.05 level. Also, the beta coefficients are in the expected positive direction. These results indicates that an increase of one on the federalism variables lead to 0.55 or 0.55 unit increase in foreign direct investment for 6- 
and 9-dimension federalism, respectively. These results are robust to control for the level of trade, democracy, central bank independence, time variable, as well as an indicator variable for whether a country is a member state of the $\mathrm{OECD}^{3}$.

An important thing to notice about these results is that while these models do not feature as large a battery of controls as is typical of this research agenda, it does include a lagged dependent variable, which allows us to control for the most significant factors by including previous amount of the inflow of FDI in the right-hand side. Because the same factors which were influencing the inflow of FDI into a country in year $t$ - 1 are also at work in determining the level of foreign investment in year $t$, the inclusion of the lagged dependent variable allows us to indirectly model these factors in a regression.

Table 2 reports results from the analyses run which utilized the IMF's GFS data. Model 1 reports the assessed impact of fiscal federalism, conceptualized as the subnational taxation expressed as a percent of the overall taxation rate. Model 2 reports the impact of fiscal federalism, conceptualized as the subnational spending as a percentage of the overall spending. Model 3 reports an interactive model of fiscal federalism.

Table 3. The Impact of Fiscal Federalism on the Inflow of Foreign Direct Investment

\begin{tabular}{lccc}
\hline & $(1)$ & $(2)$ & $(3)$ \\
VARIABLES & Model I & Model II & Model 3 \\
\hline \multirow{2}{*}{ Lag FDI } & & & \\
& 2.84 & 2.99 & 3.16 \\
Subnational Revenue & $(2.35)$ & $(2.32)$ & $(2.14)$ \\
& -0.0171 & & 0.0785 \\
& $(0.01955)$ & & $(0.0505)$
\end{tabular}

${ }^{3}$ Kauffman rule of law variable was not included in these regressions due to data unavailability. 


\begin{tabular}{lccc} 
Subnational Expenditures & & -0.0232 & 0.034 \\
Rev*Spend & & $(0.0234)$ & $(0.0379)$ \\
& & & $-0.0026^{* *}$ \\
Logged Trade & $-1.3543^{*}$ & $-1.484^{*}$ & $-1.4707^{* *}$ \\
Kauffman Rule of Law & $(0.72)$ & $(0.8339)$ & $(0.699)$ \\
& 0.0279 & 0.0905 & $0.3738^{*}$ \\
Democracy & $(0.1681)$ & $(0.1633)$ & $(0.2106)$ \\
& $-0.0815^{* *}$ & $-0.0933^{*}$ & $-0.1556^{* * *}$ \\
Central Bank Independence & $(0.0401)$ & $(0.0407)$ & $(0.0504)$ \\
& 0.6863 & 0.2285 & 1.5218 \\
Year & $(1.491)$ & $(1.043)$ & $(1.5383)$ \\
& $0.142 *$ & $0.1601 *$ & $0.2121 *$ \\
OECD & $(0.0788)$ & $(0.0848)$ & $(0.0798)$ \\
& $1.4724 * *$ & $1.5759 * *$ & $1.4403 * *$ \\
Constant & $(0.6925)$ & $(0.7547)$ & $(0.6263)$ \\
& -256.3904 & $-291.9607 *$ & $-397.1185^{*}$ \\
Number of Observations & $(156.0273)$ & $(36.8731)$ & $(157.9701)$ \\
\hline
\end{tabular}

Robust standard errors in parentheses $* * * \mathrm{p}<0.01, * * \mathrm{p}<0.05, * \mathrm{p}<0.1$

As we can see from the Table 2, neither of the fiscal federalism variables is significant in either of the regressions. Interestingly, however, they are also both in the opposite direction of what is expected according to the theory. The results in the tables would lead one to conclude that an increase in sub-national units' ability to tax and spend independently of the central government lead to lower levels of foreign investment. However, it is also important to notice that the beta coefficients are substantively and statistically insignificant. Another oddity of these results is that according to these analyses, trade exerts a significant negative relationship! This is contrary to both previous results and the literature. Additionally, Democracy variable is now significant and is also negative.

Because of these deviations in findings from previous results and literature, I also ran an interactive model of fiscal federalism. Theoretically, it is plausible to suppose that 
federalism can exert an influence on the inflow of FDI only if the subnational government(s) have the ability to both tax and spend independently. The results of the regression purport that there is, in fact, an interactive effect. The t-statistic on the interaction variable is equal to $-2.22^{4}$, with the corresponding p-value of 0.027 , which is significant at a 0.05 level. Oddly enough, however, both trade and democracy variables are highly statistically significant in the opposite direction from what is expected.

As Brambor et al. (2006) point out, however, in order to demonstrate significance of an interaction variable, it is best to provide a marginal effects graph. Hence, below is the marginal effects plot that provides graphical results of Model 3's interaction term.

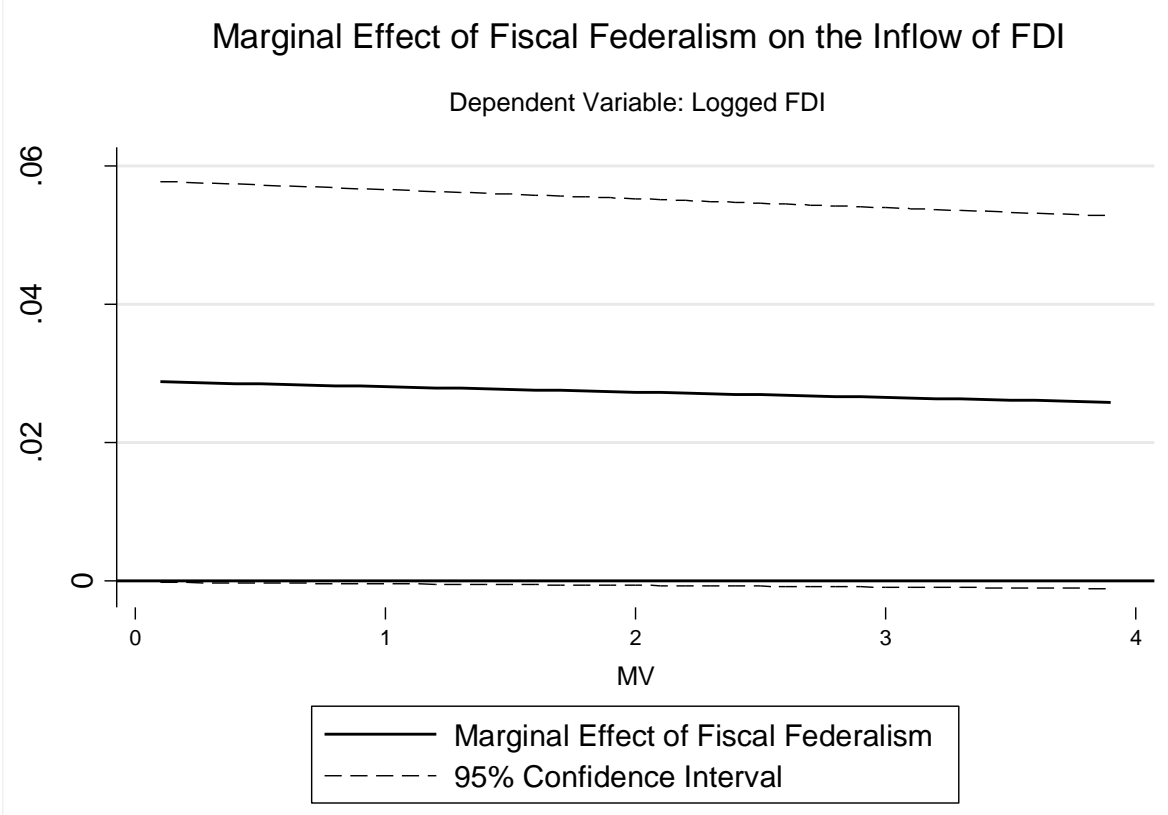

\section{Figure 5: Marginal Effect of Fiscal Federalism}

\footnotetext{
${ }^{4}$ The figures in the table itself lead to a t-statistics that is equal to exactly two. The difference in this result and the value provided by the statistical software is due to the rounding error.
} 
Next, Table 3 reports the findings of the impact of political federalism on the inflow of FDI. Because the data available contains separate measures for the presence of local and provincial elections, the analyses were run utilizing both additive and multiplicative combinations of the two. Model 1 reports the estimated relationship between federalism and FDI by separately estimating the significance of the two variables, while Model 2 reports the estimated relationship between federalism and FDI utilizing an additive measure of political federalism; whereas Model 3 reports the estimated relationship between a multiplicative measure of political federalism.

Table 4: The Impact of Political Federalism on the Inflow of Foreign Direct Investment

\begin{tabular}{|c|c|c|c|}
\hline VARIABLES & $\begin{array}{c}(1) \\
\text { Model I }\end{array}$ & $\begin{array}{c}(2) \\
\text { Model II } \\
\end{array}$ & $\begin{array}{c}(3) \\
\text { Model III } \\
\end{array}$ \\
\hline Lag FDI & $\begin{array}{l}4.26^{*} \\
(2.40)\end{array}$ & $\begin{array}{c}4.60 * * \\
(2.53)\end{array}$ & $\begin{array}{l}4.30^{*} \\
(2.43)\end{array}$ \\
\hline Municipal Elections & $\begin{array}{c}-0.5661 \\
(0.4072)\end{array}$ & & $\begin{array}{c}-1.2277 * * \\
(0.4969)\end{array}$ \\
\hline State Elections & $\begin{array}{c}0.4525 \\
(0.2366)\end{array}$ & & $\begin{array}{c}-0.8708 \\
(1.1859)\end{array}$ \\
\hline Additive & & $\begin{array}{c}-0.0254 \\
(0.2128)\end{array}$ & \\
\hline Multiplicative & & & $\begin{array}{c}0.7048 \\
(0.6582)\end{array}$ \\
\hline Logged Trade & $\begin{array}{c}1.0763 * * \\
(0.3603)\end{array}$ & $\begin{array}{l}1.0356^{* * *} \\
(0.3463)\end{array}$ & $\begin{array}{l}1.0525 * * \\
(0.3573)\end{array}$ \\
\hline Kauffman Rule of Law & $\begin{array}{c}0.1533 \\
(0.2611)\end{array}$ & $\begin{array}{c}0.2215 \\
(0.2478)\end{array}$ & $\begin{array}{c}0.1114 \\
(0.2472)\end{array}$ \\
\hline Democracy & $\begin{array}{c}0.0662 \\
(0.0552)\end{array}$ & $\begin{array}{l}0.0396 \\
(0.038)\end{array}$ & $\begin{array}{c}0.0626 \\
(0.0538)\end{array}$ \\
\hline Central Bank Independence & $\begin{array}{l}-1.0464 \\
(1.5507)\end{array}$ & $\begin{array}{l}-1.2276 \\
(1.4741)\end{array}$ & $\begin{array}{l}-1.2237 \\
(1.4728)\end{array}$ \\
\hline OECD & $\begin{array}{c}0.0692 * * \\
(0.3995)\end{array}$ & $\begin{array}{c}0.6919 * \\
(0.3773)\end{array}$ & $\begin{array}{c}0.9563 * * \\
(0.4089)\end{array}$ \\
\hline Year & $\begin{array}{c}0.0692 * * * \\
(0.0186)\end{array}$ & $\begin{array}{c}0.0689 * * * \\
(0.0189)\end{array}$ & $\begin{array}{c}0.069 * * * \\
(0.0187)\end{array}$ \\
\hline Constant & $\begin{array}{c}-120.7131 * * * \\
(36.8181)\end{array}$ & $\begin{array}{c}-120.0645^{* * *} * \\
(37.3865)\end{array}$ & $\begin{array}{c}-118.9716 * * * \\
(37.5698)\end{array}$ \\
\hline
\end{tabular}




\section{Robust standard errors in parentheses $* * * \mathrm{p}<0.01, * * \mathrm{p}<0.05, * \mathrm{p}<0.1$}

As we can see, the results are rather disappointing. In all three models run, none of the political federalism variables - state and local elections separately, added together, or multiplied by each other- are significant in any of the models. In fact, the only other variable that achieves statistical significance is the logged trade variable. From technical standpoint, these results are easy to understand. As mentioned in the discussion of variables used in the analyses, the measures for political federalism were very crude and hence unable to effectively capture the concept they were meant to measure. The problem for further research, however, is that the data might simply not exist (yet). The Database of Political Institutions' state and muni variables are the only two measures known to the author of this project that come close to accomplishing the set objective however crude.

To recap the findings, while I find that given a fairly restrictive sample, administrative federalism exerts a highly significant positive effect on the inflow of foreign direct investment, the results for fiscal federalism are much more mixed with only an interactive measure of fiscal federalism achieving weak statistical significance. On the other hand, political federalism variable is insignificant in all tests ${ }^{5}$.

\section{Race to the Bottom and Fiscal Federalism}

One of the reasons why fiscal federalism turned out insignificant in the analyses conducted above may have dealt with the so-called "race to the bottom" thesis. As was noted in the introductory sections of this paper, nations around the world are actively

\footnotetext{
${ }^{5}$ Initially, the analyses were run without the control variable for the central bank independence. Those tables can be found in appendix III of this paper.
} 
engaged in the competition for foreign direct investment. Due to the ludicrous benefits often subscribed to FDI, governments seek to employ various policy schemes designed to attract multinationals to invest in their country. One of the most popular policies is lowering (foreign and/or domestic) corporate taxation rates (Blochliger \& Campos 2011, $5)$.

By lowering taxation rates, a nation seeks to make itself a more favorable investment target. The logic is quite simple: the lower the taxation rates, the more likely is a corporation to invest in that country. This occurs due to the fact that lower taxation rates decrease the costs of operating in a country, thereby increasing a corporation's profits. Corporations, obviously operating on the principle of maximizing their profits, then, naturally seek to investment in countries that have lower interest rates.

Hence, it is possible that the reason why fiscal federalism variable did not turn out significant was due to the "polluting effect" of decreased taxation rates. It is possible that while some nations were decentralizing, other nations were improving their attractiveness by decreasing the taxation rates. Because the effective rates of taxation are not explicitly controlled for in the models conducted, there is no way of knowing whether this is actually what is going on here. The problem with this argument, however, is the fact that such move towards decreasing taxation rates is ubiquitous across almost all nations, so it is unlike to "pollute" the results of these regressions.

I now turn to the concluding remarks concerning the results of the empirical analyses carried out above, as well as their scholarly and policy implications. I will conclude by pointing out avenues for future research. 


\section{Concluding Remarks}

The results reported in this project are rather surprising and revealing. The fact that administrative federalism is so highly significant, while fiscal federalism, which, given the amount of enthusiasm among both scholars and policymakers, does not seem to exert a robust positive statistical significance, indicates that strategies that are believed by development scholars as the fundamental pillars of successful economic growth and development should be questioned. It also suggests that the uniform movement towards decentralization as a cure of all ills of poor governance has been overemphasized and that policymakers need to be more discerning when implementing such drastic changes in the operation of government.

On the other hand, these results can easily and logically be explained. While subnational governments may possess the ability to collect tax and spend the generated revenue indicates a substantial ability of subnational government to maintain autonomous existence, without substantial policy autonomy, such "independence" is essentially useless. Indeed, these findings may lead one to conclude that fiscal federalism is a necessary, but not a sufficient condition for attracting higher inflows of foreign direct investment. Perhaps, it is only the combination of fiscal and policy autonomy that are significant in convincing multinational corporations that a country is safe to invest in.

The validity of the analyses carried out in this project and their findings are additionally strengthened by the fact that the hypothesized relationships were assessed for a lengthy period of time. For example, Henderson's data which assesses the impact of administrative federalism, was only available for the years 1965 (not used here), 1975, 
and 1985. Furthermore, the fact that the sample sizes in each of the regressions was relatively small serves as an additional confirmation that regressions reports a meaningful significance on the main variables that exists in the real world, rather than being statistical artifacts created by large sample size.

This research agenda may have a broad and interesting future depending on the data availability. Because positive scholarship on federalism is relatively young, the difficulty in conducting research in this area lies in the fact that effectively operationalized measures of its different types and dimensions are lacking. Hence, the first steps to take in the right direction is for scholars to turn their attention on figuring out the most valid ways of recording measures of federalism. Fortunately, as the literature review in this paper has demonstrated, scholars have already begun laying down the path. Unfortunately, however, this work remains the domain of individual scholars rather than an effort by comparative and international politics scholars as a community in building new datasets which would provide extensive knowledge and measures of federalism.

Once data is available, it would be interesting to see studies assessing the impact of federalism on a wide variety of social and political phenomena. Hopefully, new and improved data will significantly help alleviate the problem of insignificant and contradictory findings and will allow political science to accumulate knowledge in this area of research. 


\section{Bibliography}

Achen, Christopher H. 2000. "Why Lagged Dependent Variable Can Suppress the Explanatory Power of Other Independent Variables.” Presented at the Annual Meeting of the Political Methodology, Los Angeles.

Arzaghi, Mohammad, and J. Vernon Henderson. 2005. "Why Countries Are Fiscally Decentralizing?” Journal of Public Economics 89(7): 1157-1189.

Bahl, Roy. 1999. "Fiscal Decentralization as Development Policy.” Public Budgeting and Finance 19(2): 59-75.

Bernard, Andrew B., and J. Bradford Jensen. 2004. "Why Some Firms Export." The Review of Economics and Statistics 86(2): 561-569.

Bird, Richard M. 1993. "Threading the Fiscal Labyrinth: Some Issues in Fiscal Decentralization.” National Tax Journal 46(2): 207-27.

Blochliger, H., and J. Pinero Campos. 2011. "Tax Competition Between Sub-Central Governments.” OECD Working Paper No. 13.

Blomstrom, Magnus, and Ari Kokko. 2003. "The Economics of Foreign Direct Investment Incentives.” NBER Working Paper No. 9489.

Blume, Lorenz, and Stefan Voigt. 2008. "Federalism and Decentralization: A Critical Survey of Frequently Used Indicators." Working Paper Joint Discussion Paper Series in Economics (University of Marburg). 
Breton, Albert. 2000. "Federalism and Decentralization: Ownership Rights and the Superiority of Federalism." Publius 30(2): 1-16.

Buchanan, James, and Brennan Geoffrey. 1980. The Power to Tax: Analytical Foundations of a Fiscal Constitution. Cambridge, NY: Cambridge University Press.

Capello, Roberta, and Tomaz Ponce Dentinho, Eds. 2012. Globalization Trends and Regional Development: Dynamics of FDI and Human Capital Flows. Northampton, MA: Edward Elgar.

Casi, Laura, and Laura Remini. 2012. “Globalization, Foreign Direct Investment and Growth in European Regions: an Empirical Assessment.” In Globalization Trends and Regional Development: Dynamics of FDI and Human Capital Flows, eds. Roberta Capello and Tomaz Ponce Dentinho.

Chan, Steve, ed. 1995. Foreign Direct Investment in a Changing Global Political Economy. New York, NY: St. Martin's Press.

Chen, Chung. 1995. “The Role of Foreign Direct Investment in China's post-1978 Economic Development.” World Development 23(4): 671 - 703.

Collier, Paul, and Jan W. Gunning. 1999. "Explaining African Economic Performance." Journal of Economic Literature 13(3): 3-22.

Cukierman, Alex, and Steven B. Webb. 1995. "Political Influence on Central Bank: International Evidence.” The World Bank Economic Review 9(3): 397 - 423. 
Dutt, Amitava Krishna. 1998. "Globalization, Foreign Direct Investment and Southern Growth: Evidence from Selected Asian Countries." In Economic Effects of Globalization, ed. John-ren Chen. Brookfield, VT: Ashgate Publishing Ltd, 4596.

Fan, C. Simon, Chen Lin, and Daniel Treisman. 2008. "Political Decentralization and Corruption: Evidence from Around the World." Journal of Public Economics (93): 14-34.

Globerman, Steven, and Daniel Shapiro. 2002. "Global Foreign Direct Investment Flows: the Role of Governance Infrastructure." World Development 30(11): 1899-1919.

Harding, Torfinn, and Beata S. Javorcik. 2011. "Roll Out the Red Carpet and They Will Come: Investment Promotion and FDI Inflows.” The Economic Journal 121(557): $1445-1476$.

Hayek, Friedrich A. 1945. "The Use of Knowledge in Society." American Economic Review 4(35): 519-530.

International Monetary Fund. Government Finance Statistics. ICPSR08624-v2. Ann Arbor, MI: Inter-University Consortium for Political and Social Research [distributor] 2010-07-26. doi:10.3886/ICPSR08624.v2

Javorcik, Beata S. 2004. "Does Foreign Direct Investment Increase the Productivity of Domestic Firms? In Search of Spillovers through Backward Linkages.” The American Economic Review 94(3): 605-627. 
Jensen, Nathan. 2003.'Democratic Governance and Multinational Corporations: The Political Economy of Foreign Direct Investment.” International Organization 57 (3): 587-616.

Jensen, Nathan. 2008. Political Risk, Democratic Institutions, and Foreign Direct Investment. Journal of Politics 70(4): 1040-1052.

Jensen, Nathan, Glen Biglaiser, Quan Li, Edmund Malesky, Pablo Pinto, Santiago Pinto, and Joseph Staats. 2012. Politics and Foreign Direct Investment (Michigan Studies in International Political Economy). Ann Arbor, MI: University of Michigan Press.

Jin, Jing, and Heng-fu Zou. 2002. "How Does Fiscal Decentralization Affect Aggregate, National, and Subnational Government Size?" Journal of Urban Economics 52: 270-293.

Keele, Luke, and Nathan J. Kelly. 2005. "Dynamic Models for Dynamic Theories: the Ins and Outs of Lagged Dependent Variables.” Political Analysis 14(2): 186-205.

Kessing, Sebastian G., Kai A. Konrad, and Christos Kotsogiannis. 2007. "Foreign Direct Investment and the Dark Side of Decentralization.” Economic Policy 22(49): 570.

Klaus Armingeon, Romana Careja, Laura Knöpfel, David Weisstanner, Sarah Engler, Pana-jotis Potolidis, Marlène Gerber. 2013. Comparative Political Data Set III 1990-2011. Bern: Institute of Political Science, University of Berne. 
Li, Quan. 2006. "Democracy, Autocracy, and Tax Incentives to Foreign Direct Investors: A Cross-National Analysis." Journal of Politics 68: 62-74.

Li, Quan, and Adam Resnik. 2003. "Reversal of Fortunes: Democratic Institutions and Foreign Direct Investment Inflows to Developing Countries." International Organization 57(1): 175-211.

Marks, Gary, Liesbet Hooghe, and Arjan H. Schakel. 2008. "Measuring Regional Authority." Regional and Federal Studies 18(2,3): 111-121.

Marshall, M. G., \& Jaggers, K. (2002). Polity IV project: Political regime characteristics and transitions, 1800-2002.

Martinez-Velasquez, Jorge, and Andrey Timofeev. 2010. "Decentralization Measures Revisited.” International Studies Program. Working Paper09-13.

das Neves, Joao Cesar. 2012. "Globalization and Geographical Growth Patterns." In Globalization Trends and Regional Development: Dynamics of FDI and Human Capital Flows. eds. Roberta Capello and Tomaz P. Dentinho.

Nooruddin, Irfan. 2011. Coalition Politics and Economic Development: Credibility and the Strength of Weak Governments. New York, NY: Cambridge University Press.

Oates, Wallace E. 1985. "Searching for Leviathan: An Empirical Study." The American Economic Review 75(4): 748-57.

OECD, 2002. Foreign Direct Investment in Development: Maximizing Benefits, Minimizing Costs. Paris, OECD. 
OECD. 2008. OECD Benchmark Definition of Foreign Direct Investment. Paris, OECD.

Oxelhelm, Lars, ed. 1993. The Global Race for Foreign Direct Investment: Prospects for the Future. New York, NY: Springer-Verlag.

Przeworski, Adam, and Fernando Limongi. 1993. "Political Regimes and Economic Growth.” The Journal of Economic Perspectives 7(3): 51-69.

Qian, Yingyi, and Barry R. Weingast. 1997. "Federalism as a Commitment to Preserving Market Incentives.” The Journal of Economic Perspectives 11(4): 83-92.

Ricker, William H. 1964. Federalism: Origins, Operation Significance. Boston, MA: Little, Brown.

Rodden, Jonathan. 2004. "Comparative Federalism and Decentralization: On Meaning and Measurement." Comparative Politics 36(4):

Rondinelli, Dennis A., James S. McCullough, and Ronald W. Johnson. 1989. “Analysing Decentralization Policies in Developing Countries: a Political-Economy Framework." Development and Change (20): 57-87.

Schneider, Aaron. 2003. "Decentralization: Conceptualization and Measurement." Studies in Comparative International Development 38(3): 32-56.

De Soysa, Indra. 2003. Foreign Direct Investment, Democracy, and Development: Assessing Contours, Correlates, and Concomitants of Globalization. New York, NY: Routledge. 
Stein, Ernesto. 1999. "Fiscal Federalism and Government Size in Latin America." Journal of Applied Economics 2(2): 357-391.

Strasavage, David. 2002. "Private Investment and Political Institutions." Economics and Politics 14(1): 41-63.

Thorsten Beck, George Clarke, Alberto Groff, Philip Keefer, and Patrick Walsh, 2001. "New Tools in Comparative Political Economy: The Database of Political Institutions." 15:1, 165-176 (September), World Bank Economic Review.

Tiebout, Charles M. 1956. “A Pure Theory of Local Expenditures.” Journal of Political Economy 64(5): 416-424.

Treisman, Daniel. 1999. "Political Decentralization and Economic Reform: A GameTheoretic Analysis.” American Journal of Political Science 43(2): 488-517.

Treisman, Daniel. 2000. "The Causes of Corruption: a Cross-National Study." Journal of Public Economics 76(3): 399-457.

Tsebelis, George. 1995. "Decision Making in Political Systems: Veto Players in Presidentialism, Parliamentarism, Multicameralism and Multipartyism." British Journal of Political Science 25(3): 289-325.

Villaverde, Jose, and Adolfo Maza. 2012. "Inward Foreign Direct Investment in the European Union. Regional Distribution and Determinants."

Wang, Yanling. 2010. "FDI and Productivity Growth: the Role of Inter-Industry Linkages." The Canadian Journal of Economics/Revue canadienne d'Economique 43(4): $1243-1272$. 
Weingast, Barry R. 1995. "The Economic Role of Political Institutions: MarketPreserving Federalism and Economic Development." Journal of Law, Economics, and Organization 11(1): 1-31.

White, Stacey. 2011. "Government Decentralization in the $21^{\text {st }}$ Century." Center for $\begin{array}{lll}\text { Strategic and International Studies } & \end{array}$ http://csis.org/files/publication/120329_White_Decentralization_Web.pdf.

Wooldridge, Jeffry M. 2006. Introductory Econometrics: A Modern Approach. Mason, $\mathrm{OH}$ : South-Western.

World Bank. 2014. World Development Indicators. Washington, DC. (http://data.worldbank.org/data-catalog/world-development-indicators)

Zhang, Yan, Haiyang Li, Yu Li, and Li-An Zhou. 2010. "FDI Spillover in an Emerging Market: the Role of Foreign Firms' Country Origin Diversity and Domestic Firms’ Absorptive Capacity.” Strategic Management Journal 31(9): 969-989. 


\section{Appendix I: Summary Statistics}

\begin{tabular}{r|rrrrr} 
Variable & Obs & Mean & Std. Dev. & Min & Max \\
\hline ccode & 8881 & 449.1746 & 263.2077 & 2 & 990 \\
year & 8893 & 1991.72 & 12.31511 & 1970 & 2012 \\
fdi & 6613 & $3.38 e+09$ & $1.71 e+10$ & $-2.83 e+10$ & $3.40 e+11$ \\
lfdi & 6044 & 18.6749 & 3.02298 & 2.302585 & 26.5524 \\
fiscfedtax & 1251 & 22.54181 & 18.24337 & .2 & 93.8 \\
\hline fiscfedspend & 1122 & 23.46114 & 15.09689 & .4 & 98.8 \\
Democracy & 6507 & .9127094 & 7.431338 & -10 & 10 \\
muni & 3634 & 1.275179 & .8296762 & 0 & 2 \\
state & 4680 & .7961538 & .8201787 & 0 & 2 \\
author & 2153 & .4561078 & .4981855 & 0 & 1 \\
\hline fed6 & 144 & 1.417593 & 1.296939 & 0 & 4 \\
fed9 & 146 & 1.226027 & 1.085792 & 0 & 3.555556 \\
trade & 6696 & 64.18218 & 49.68401 & 4.95 & 986.65 \\
ltrade & 6696 & 3.977761 & .5996164 & 1.599388 & 6.894315 \\
oecd & 8895 & .1225408 & .3279277 & 0 & 1 \\
\hline CBI & 1972 & .3386004 & .1265002 & .09 & .69
\end{tabular}

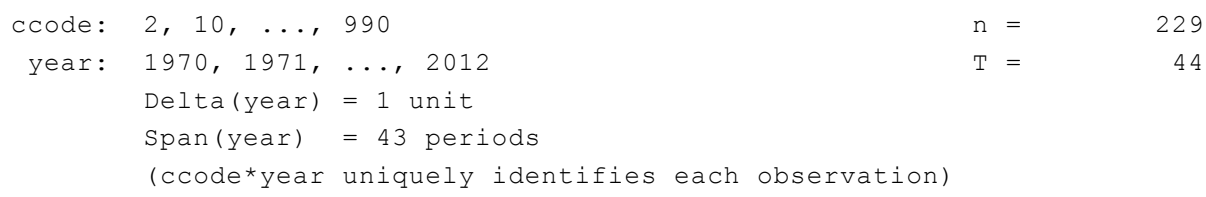

\begin{tabular}{|c|c|c|c|}
\hline Freq. & Percent & Cum. & Pattern \\
\hline 139 & 60.70 & 60.70 & 1111111111111111111111111111111111111111 \\
\hline 49 & 21.40 & 82.10 & . .1111111111111111111111111111111111111111 \\
\hline 15 & 6.55 & 88.65 & $\ldots \ldots \ldots \ldots \ldots \ldots \ldots \ldots \ldots 1.1 .11111111111$ \\
\hline 5 & 2.18 & 90.83 & .111111111111111111111111111111111111111111 \\
\hline 2 & 0.87 & 91.70 & $\ldots \ldots \ldots \ldots \ldots \ldots \ldots \ldots \ldots \ldots \ldots \ldots 111111$ \\
\hline 1 & 0.44 & 92.14 & 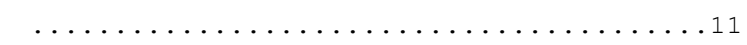 \\
\hline 1 & 0.44 & 92.58 & $\ldots \ldots \ldots \ldots \ldots \ldots \ldots \ldots \ldots 11111111111111111$ \\
\hline 1 & 0.44 & 93.01 & $\ldots \ldots \ldots \ldots \ldots \ldots \ldots 11111111111111111111$ \\
\hline 1 & 0.44 & 93.45 & 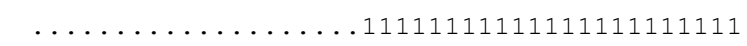 \\
\hline 15 & 6.55 & 100.00 & (other patterns) \\
\hline
\end{tabular}


Appendix II: TSLINE - FDI

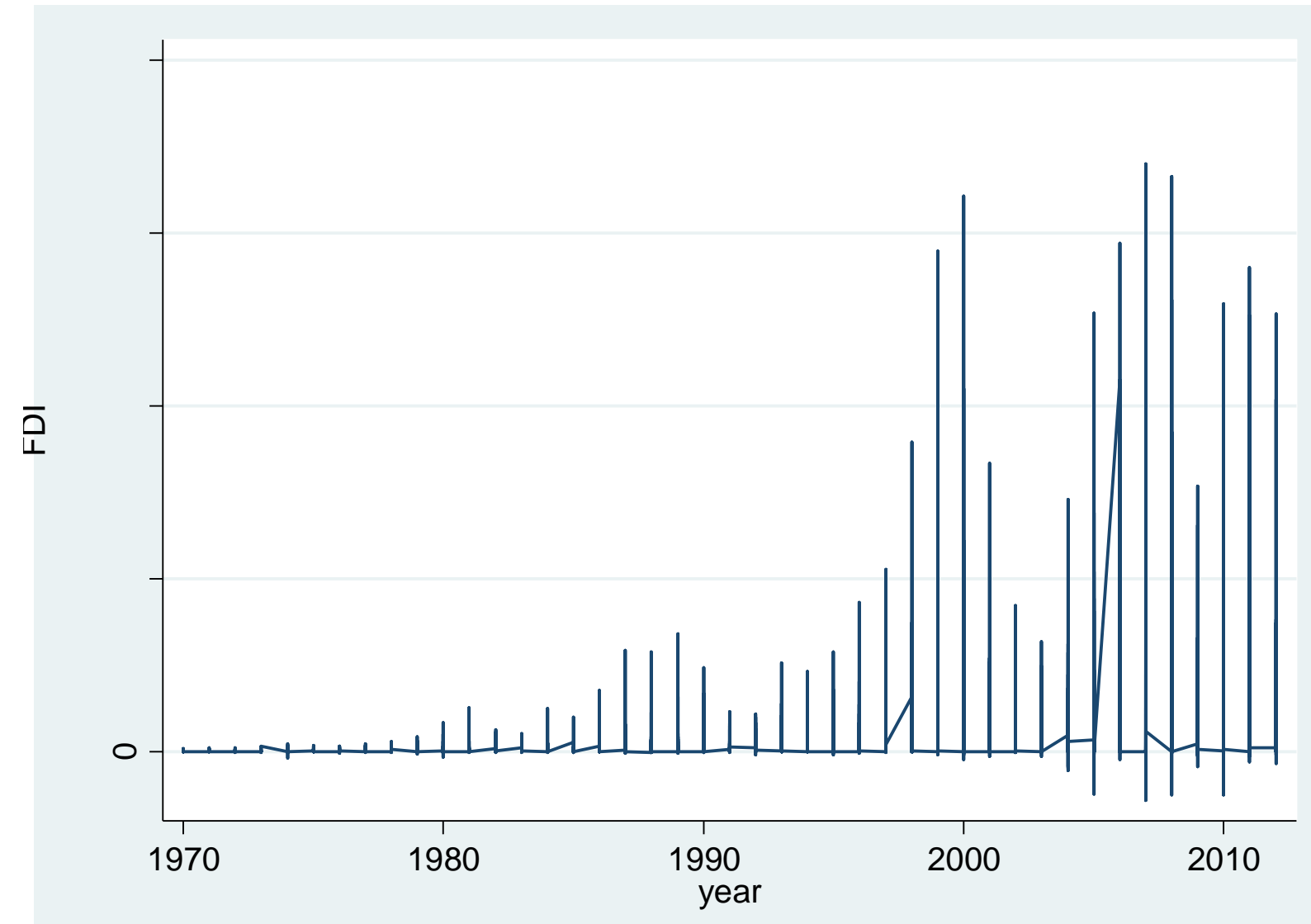




\section{Appendix III: Regression Results With Central Bank Independence Control Omitted}

The Impact of Administrative Federalism on the Inflow of Foreign Direct Investment

\begin{tabular}{lcc}
\hline & $(1)$ & $(2)$ \\
VARIABLES & Model I & Model II \\
\hline \multirow{2}{*}{ Lag FDI } & $-7.62 * * *$ & $-8.01 * * *$ \\
Federalism, 6-dimension & $(2.17)$ & $(2.32)$ \\
& $0.7702^{* * *}$ & \\
Federalism, 9-dimension & $(0.2087)$ & \\
& & $0.9271 * * *$ \\
Logged Trade & & $(0.2413)$ \\
& $1.0697 * *$ & $1.0144 * *$ \\
Democracy & $(0.4032)$ & $(0.4095)$ \\
& 0.0443 & 0.0216 \\
OECD & $(0.0496)$ & $(0.0550)$ \\
& $1.0540^{*}$ & $1.279 * *$ \\
Year & $(0.5930)$ & $(0.6241)$ \\
& $0.0263 * *$ & 0.0705 \\
Constant & $(0.6348)$ & $(0.0250)$ \\
& $-116.7515^{* *}$ & $-126.1677 * * *$ \\
& $(51.40866)$ & $(48.991)$
\end{tabular}

Robust standard errors in parentheses $* * * \mathrm{p}<0.01, * * \mathrm{p}<0.05, * \mathrm{p}<0.1$ 
The Impact of Fiscal Federalism on the Inflow of Foreign Direct Investment

\begin{tabular}{lccc}
\hline & $(1)$ & $(2)$ & $(3)$ \\
VARIABLES & Model I & Model II & Model 3 \\
\hline \multirow{2}{*}{ Lag FDI } & $1.02 * *$ & $1.04 * *$ & $2.14 * *$ \\
Subnational Revenue & $(3.42)$ & $(4.13)$ & $(1.05)$ \\
& -0.0057 & & $0.0288 * *$ \\
Subnational & $(0.0111)$ & & $(0.0139)$ \\
Expenditures & & -0.0032 & $0.0257 *$ \\
Rev*Spend & & $(0.0104)$ & $(00137)$ \\
& & & $-0.0008 * *$ \\
Logged Trade & & & $(0.0003)$ \\
& $-0.8453 * *$ & $-0.8888^{* *}$ & $-1.3695 * * *$ \\
Kauffman Rule of Law & $(0.2775)$ & $(0.2909)$ & $(0.1883)$ \\
& 0.455 & $04928 *$ & $0.4124 * *$ \\
Democracy & $(0.275)$ & $(0.2656)$ & $(01511)$ \\
& $-0.0459 * *$ & $-0.0375 * *$ & $-0.0526 * * *$ \\
Year & $(0.0201)$ & $(0.0174)$ & $(0.0164)$ \\
& $0.1632 * * *$ & $0.1628 * * *$ & $0.1234 * * *$ \\
OECD & $(0.0 .0177)$ & $(0.01867)$ & $(0.0201)$ \\
& $1.6388 * *$ & $1.5731 * *$ & $1.4841 * * *$ \\
Constant & $(0.7548)$ & $(0.7238)$ & $(0.2744)$ \\
& $-302.1547 * *$ & $-301.1806 * * *$ & $-221.0722 * * *$ \\
& $(35.0066)$ & $(36.8731)$ & $(40.036)$
\end{tabular}

Robust standard errors in parentheses $* * * \mathrm{p}<0.01, * * \mathrm{p}<0.05, * \mathrm{p}<0.1$ 
The Impact of Political Federalism on the Inflow of Foreign Direct Investment

\begin{tabular}{|c|c|c|c|}
\hline VARIABLES & $\begin{array}{c}(1) \\
\text { Model I }\end{array}$ & $\begin{array}{c}(2) \\
\text { Model II }\end{array}$ & $\begin{array}{c}(3) \\
\text { Model III }\end{array}$ \\
\hline Lag FDI & $\begin{array}{c}-3.25^{* *} \\
(1.28)\end{array}$ & $\begin{array}{c}3.26 * * \\
(1.28)\end{array}$ & $\begin{array}{c}3.24 * * \\
(1.28)\end{array}$ \\
\hline Municipal Elections & $\begin{array}{c}0.0000 \\
(0.0004)\end{array}$ & & $\begin{array}{c}0.0857 \\
(0.2024)\end{array}$ \\
\hline State Elections & $\begin{array}{c}-0.0002 \\
(0.0004)\end{array}$ & & $\begin{array}{c}-0.0003 \\
(0.0004)\end{array}$ \\
\hline Additive & & $\begin{array}{l}-0.0001 \\
(0.0001)\end{array}$ & \\
\hline Multiplicative & & & $\begin{array}{c}0.0001 \\
(0.0002)\end{array}$ \\
\hline Logged Trade & $0.8437 * * *$ & $0.8431 * * *$ & $\begin{array}{c}0.8435^{* *} \\
*\end{array}$ \\
\hline & $(0.2448)$ & $(0.2447)$ & $(0.2454)$ \\
\hline Kauffman Rule of Law & $\begin{array}{c}0.7071 * * * \\
(0.1937)\end{array}$ & $\begin{array}{c}0.7071 * * * \\
(0.1926)\end{array}$ & $\begin{array}{c}0.7046 * * \\
* \\
(0.1941)\end{array}$ \\
\hline Democracy & $\begin{array}{c}0.0188 \\
(0.0199)\end{array}$ & $\begin{array}{c}0.0187 \\
(0.0197)\end{array}$ & $\begin{array}{l}0.0176 \\
(0.021)\end{array}$ \\
\hline OECD & $\begin{array}{c}1.4854 * * \\
(0.5897)\end{array}$ & $\begin{array}{l}1.487 * * \\
(0.5888)\end{array}$ & $\begin{array}{c}1.4524 * * \\
(0.5898)\end{array}$ \\
\hline Year & $0.1178 * * *$ & $0.1178 * * *$ & $\begin{array}{c}0.1174 * * \\
*\end{array}$ \\
\hline \multirow{3}{*}{ Constant } & $(0.0102)$ & $\begin{array}{c}(0.0103) \\
2102051 * * *\end{array}$ & $\begin{array}{c}(0.0103) \\
-\end{array}$ \\
\hline & $-219.2919 \cdots$ & $-219.2951 \cdots$ & $\begin{array}{c}218.6012 \\
* * *\end{array}$ \\
\hline & (20.5119) & (20.5004) & $(20.5246)$ \\
\hline
\end{tabular}

Robust standard errors in parentheses

*** $\mathrm{p}<0.01, * * \mathrm{p}<0.05$, * $\mathrm{p}<0.1$ 